\title{
Effect of chromium on growth, biochemicals and nutrient accumulation of paddy (Oryza sativa L.)
}

\author{
M. Nagarajan ${ }^{1}$, K. Sankar Ganesh ${ }^{2, *}$ \\ ${ }^{1}$ Research and Development Centre, Bharathiyar University, Coimbatore - 641 046, India \\ ${ }^{2}$ Department of Botany, A.V.C. College, Mannampandal, Mayiladuthurai, India \\ *E-mail address: indsankar@rediffmail.com
}

\begin{abstract}
Chromium is a heavy metal; this element is considered as an environmental hazard. Toxicity effects of chromium on growth and development of plants including inhibition of germination process decrease of growth and biomass of plant. The aim of this research is to study accumulation of Chromium along with nutrients and its effect on the growth of Paddy plant (Oryza sativa L). Thus, paddy seedlings grown in petriplates lined with filter paper undergoing, different treatments of $\mathrm{Cr}(0$, $2.5,5,10,25,50,75,100$ and $200 \mathrm{mg} / \mathrm{L}$ ). After one week seedlings were removed and morpho physiological parameters like root length, shoot length and dry weight of plants and Biochemicals ,accumulation of nutrients along with $\mathrm{Cr}$ in roots and shoots were determined. The results indicated that the concentrations more than $100 \mathrm{mg} / \mathrm{L}$ chromium cause the reduction of morphophysiology parameters in the treatment plants rather than control plant and $\mathrm{Cr}$ addition in the cultures caused enhancement of chromium content in roots and shoots of plant seedlings. Similarly the biochemicals and nutrient accumulation also affected by increasing concentrations of chromium. It was also noted that accumulation of chromium in the roots was much higher than the shoots of the seedlings under treatment.
\end{abstract}

Keywords: Accumulation; Chromium; Biochemicals; Growth; Heavy metal; paddy plant

\section{INTRODUCTION}

The problem of water pollution due to industrial effluents has already become a serious threat in India. The effluent discharging industries are distilleries, detergents, electroplating plants, fertilizer units, iron and steel industries, paper and pulp, pharmaceuticals, petrochemical, pesticides and herbicide industries, oil refineries, sugar mills, thermal power plants, textile, tannery and dye industries. These industrial effluents contain a wide variety of organic and inorganic pollutants with heavy metals which create many serious physiological disorders in living organisms. Chromium is a heavy metal with risk to human health. Its presence in agricultural soils can be attributed to the use of organic wastes as fertilizer and the use of waste water for irrigation (Sankar Ganesh et al, 2008). Chromium enters the food chain through consumption of plant material. A high concentration of $\mathrm{Cr}$ has been found to be harmful to vegetation. As the chromium concentration in plants increases, it adversely affects several biological parameters. Ultimately there is loss of vegetation, and land sometimes 
becomes barren (Dube et al., 2003). In recent years, contamination of the environment by chromium has become a major concern. Chromium is used on a large-scale in many different industries, including metallurgy, electroplating, production of paints and pigments, tanning, wood preservation, chemical production, and pulp and paper production (Zayed and Terry, 2003). These industries have be-come especially large contributors of Cr pollution, which can ultimately have significant adverse biological and ecological effects. Very high levels of $\mathrm{Cr}$ (VI) contamination $(14,600 \mathrm{mg} / \mathrm{kg}$ in ground water and $25,900 \mathrm{mg} / \mathrm{kg}$ in soil) were reported at the United Chrome Products site in Corvallis, Oregon (Krishnamurthy and Wilkens, 1994). Symptoms of $\mathrm{Cr}$ phytotoxicity include inhibition of seed germination or of early seedling development, reduction of root growth, leaf chlorosis and depressed biomass (Sharma et al., 1995). There are many studies on Cr toxicity in crop plants. Chromium significantly affects the metabolism of plants such as barley (Hordeum vulgare) (Ali et al., 2004), citrullus (Dube et al., 2003), cauliflower (Chatterjee and Chatterjee, 2000), vegetable crops (Zayed et al., 1998), wheat (Triticum aestivumcv, HD2204) (Sharma et al., 1995), maize (Zea mays) (Sharma and Pant, 1994) and Soy bean and Black gram (Sankar ganesh et al, 2006). Chromium is highly toxic non-essential element for microorganism and plants (Cervantes et al., 2001).

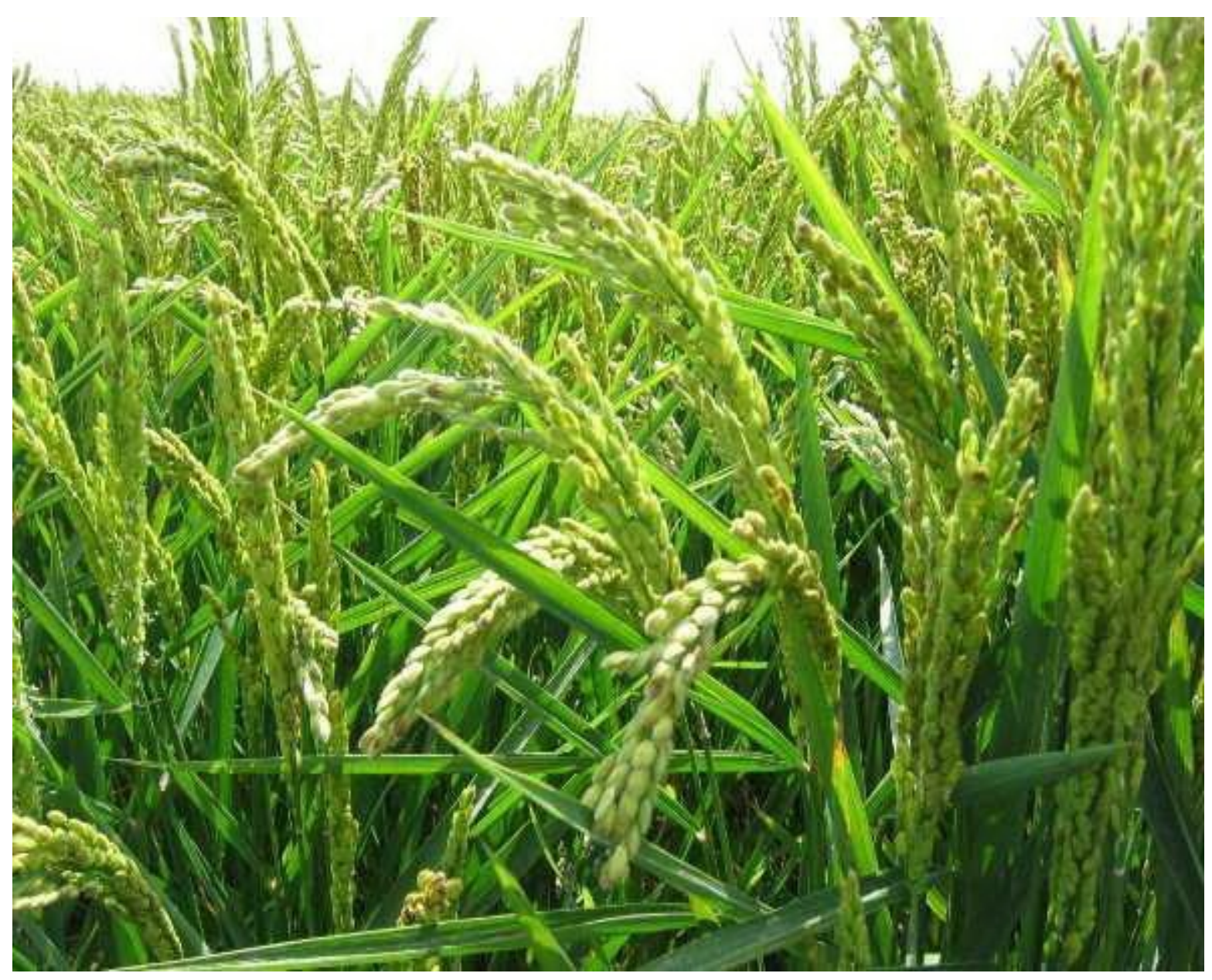

Photo 1. Oryza sativa L. 
The sources of chromium in environment are both natural and anthropogenic, natural source include burning of oil and coal, petroleum from Ferro chromate refractory material, chromium steels, pigments oxidants, catalyst and fertilizers. This element is also used in metal plating tanneries and oil well drilling (Abbassi et al., 1998). Sewage and fertilizers are also the sources of chromium (Pilay et al., 2003). Marked toxicity of chromium was found with respect to photosynthetic pigment, photosynthesis, nitrate reductase activity and protein content of some alga (Rai et al., 1992). The direct interaction of metal with cellular components can initiate variety of metabolic responses final y leading to a shift in the development of the plant (Assche and Clijsters, 1990). Chromium toxicity produces chlorosis and necrosis in plants (Cervantes et al., 2001). Several polluting metal and compounds are discharged into the water streams by tanneries. With these aspects in view, the present investigation was made to study the effect of different concentrations of chromium on the growth, mineral nutrients and Accumulation of chromium in Paddy.

\section{MATERIALS AND METHODS}

Paddy (Oryza sativa. L) seeds were obtained from the Regional Rice Research station, Aaduthurai, Tamil Nadu, India. Uniform seeds were selected and surface sterilized with $0.01 \% \mathrm{HgCl}_{2}$ solution for 2 minutes. Petriplates were lined with filter paper and treated with different concentrations (control, 2.5, 5, 10, 25, 50, 75, 100 and $200 \mathrm{mg} / 1$ ) of Chromium. Three replicates were maintained. Plant Growth were measured by using centimeter scale and recorded. The same plant samples were taken for morphological studies were also used for the determination of dry weight by using electrical single pan balance. Their dry weights were determined by keeping the plant materials in a hot air oven at $80{ }^{\circ} \mathrm{C}$ for $24 \mathrm{hrs}$ and recorded. The biochemical constituents such as Total chlorophyll (Arnon, 1949), Carotenoid (Kirk and Allen, 1965), Protein (Lowry et al., 1951), Amino acids (Moore and Stein, 1948), sugars (Nelson, 1944) and Starch(Dubois et al., 1956). The mineral elements such as Total nitrogen (Jackson, 1958), Phosphorus (Black, 1965), Potassium (Williams and Twine, 1960), Calcium and magnesium (Yoshida et al., 1972), manganese, iron, copper, zinc and chromium accumulation was also measured by using the method of Pipper, 1966.

\section{DISCUSSION}

In this experiment, the percentage of germination decreased with the increase of chromium concentrations. In our findings, $200 \mathrm{mg} / \mathrm{l}$ chromium concentration reduced the seed germination up to 50 to 60 per cent over control. No germination was recorded beyond $200 \mathrm{mg} / \mathrm{l}$ concentration of chromium (Table 1). Similar inhibition of germination percentage at higher concentrations of chromium was observed in soybean (Sidharthan and Lakshmanachary, 1996), mungbean (Rout et al., 1997), cowpea (Lalitha et al., 1999), groundnut (Subramani et al., 1999), blackgram (Lakshmi and Sundaramoorthy, 2003), greengram (Samantary and Deo, 2004) and paddy, blackgram and soybean (Sankar Ganesh et al., 2006b; Sundaramoorthy et al., 2006a,b). The reduction in germination percentage of plants at higher chromium concentrations may be attributed to the interference of metal ions, which may inhibit seed germination by exerting unfavourable effect on the activities of hydrolytic enzymes involved in the mobilization of major seed reservoirs such as starch, protein, RNA and phytin (Dua and Sawhney, 1991). 
The Root length and shoot length are gradually decreased with the increase in chromium concentrations (Table 1). The highest seedling length was observed in control paddy seedlings. More pronounced effect on seedling growth was observed above $75 \mathrm{mg} / \mathrm{l}$ chromium concentrations. The inhibition of root growth was influenced by the concentration of heavy metals because of the surface accumulation and sensitive to root primordia. It was more pronounced at higher concentrations of chromium (Bitell et al., 1974). In this experiment; there was a gradual decrease in seedling dry weight with the progressive increase in chromium concentrations (Table 2). The lowest dry weight of paddy seedlings was recorded in seedlings treated with $200 \mathrm{mg} / \mathrm{l}$ chromium concentrations and the highest dry weight was registered at control. The reduction in seedling dry weight was observed from 2.5 $\mathrm{mg} / \mathrm{l}$ chromium concentrations onwards. A decrease in biomass productivity might be attributed to a disruption in nitrogen metabolism of seedlings under chromium stress (Chatterjee and Chatterjee, 2000).

Table 1. Seed germination, Seedling growth ( $\mathrm{cm} /$ seedling) and Seedling dry weight $(\mathrm{g} / \mathrm{seedling})$ of paddy (Oryza sativa L.) as influenced by different concentrations of chromium.

\begin{tabular}{|c|c|c|c|c|}
\hline $\begin{array}{c}\text { Chromium } \\
\text { concentrations } \\
(\mathrm{mg} / \mathrm{l})\end{array}$ & $\begin{array}{c}\text { Germination } \\
\text { percentage }\end{array}$ & $\begin{array}{c}\text { Root length } \\
(\mathrm{cm} / \text { seedling })\end{array}$ & $\begin{array}{c}\text { Shoot length } \\
(\mathrm{cm} / \text { seedling })\end{array}$ & $\begin{array}{c}\text { Dry weight } \\
(\mathrm{g} / \text { seedling }) .\end{array}$ \\
\hline Control & $98.0 \pm 3.2$ & $10.6 \pm 0.424$ & $14.2 \pm 0.71$ & $0.256 \pm 0.0128$ \\
\hline 2.5 & $94.0 \pm 2.8$ & $10.4 \pm 0.415$ & $13.6 \pm 0.65$ & $0.223 \pm 0.0126$ \\
\hline 5 & $90.0 \pm 2.6$ & $9.5 \pm 0.325$ & $12.5 \pm 0.60$ & $0.173 \pm 0.120$ \\
\hline 10 & $84.0 \pm 2.2$ & $9.2 \pm 0.462$ & $11.2 \pm 0.07$ & $0.152 \pm 0.0116$ \\
\hline 25 & $82.0 \pm 2.0$ & $9.0 \pm 0.423$ & $10.6 \pm 0.60$ & $0.143 \pm 0.0114$ \\
\hline 50 & $74.0 \pm 1.8$ & $8.5 \pm 0.315$ & $8.7 \pm 0.55$ & $0.128 \pm 0.0042$ \\
\hline 75 & $68.0 \pm 1.6$ & $8.0 \pm 0.40$ & $7.5 \pm 0.45$ & $0.113 \pm 0.0038$ \\
\hline 100 & $58.0 \pm 1.4$ & $5.6 \pm 0.315$ & $7.2 \pm 0.014$ & $0.098 \pm 0.0049$ \\
\hline 200 & $52.0 \pm 1.2$ & $5.0 \pm 0.30$ & $6.0 \pm 0.35$ & $0.076 \pm 0.0035$ \\
\hline
\end{tabular}

\pm Standard deviation

The chlorophyll and carotenoid contents of paddy crop decreased gradually with the increase of chromium concentration. Similar findings of the reduction in chlorophyll contents of various crops treated with chromium are already reported in pea (Bishnoi et al., 1993b), wheat (Sharma and Sharma, 1993), mungbean (Samantary and Deo, 2004) and cauliflower (Chatterjee and Chatterjee, 2000). The reduction in chlorophyll content of crops may be due to the interaction of enzymes involved in the chlorophyll biosynthetic pathway could also contribute to the general reduction in chlorophyll content in most plants under chromium stress (Shanker et al., 2005). Similarly the biochemical constituents such as protein, amino acids, sugars and starch content of paddy is gradually decreased with the increase in chromium concentrations. 
Table 2. Pigments and Biochemical constituents (mg/g fr. wt) of paddy (Oryza sativa L.) under different concentrations of chromium.

\begin{tabular}{|c|c|c|c|c|c|c|}
\hline $\begin{array}{c}\text { Chromium } \\
\text { concentrations } \\
(\mathrm{mg} / \mathrm{l})\end{array}$ & $\begin{array}{c}\text { Total } \\
\text { chlorophyll } \\
\text { (mg/g } \\
\text { fr. wt) } \\
\end{array}$ & $\begin{array}{c}\text { Carotenoied } \\
\text { (mg/g } \\
\text { fr.wt) }\end{array}$ & $\begin{array}{l}\text { Protein } \\
(\mathrm{mg} / \mathrm{g} \\
\text { fr. wt) }\end{array}$ & $\begin{array}{c}\text { Aminoacids } \\
\text { (mg/g } \\
\text { fr. wt) }\end{array}$ & $\begin{array}{l}\text { Sugars } \\
\text { (mg/g } \\
\text { fr. wt) }\end{array}$ & $\begin{array}{l}\text { Starch } \\
(\mathrm{mg} / \mathrm{g} \\
\text { fr. wt) }\end{array}$ \\
\hline Control & $1.234 \pm 0.06$ & $0.857 \pm 0.05$ & $1.113 \pm 0.07$ & $1.760 \pm 0.07$ & $4.350 \pm 0.34$ & $3.767 \pm 0.19$ \\
\hline 2.5 & $0.875 \pm 0.06$ & $0.639 \pm 0.05$ & $1.092 \pm 0.06$ & $1.533 \pm 0.07$ & $4.112 \pm 0.24$ & $3.521 \pm 0.17$ \\
\hline 5 & $0.765 \pm 0.06$ & $0.498 \pm 0.04$ & $1.007 \pm 0.05$ & $1.270 \pm 0.06$ & $3.542 \pm 0.22$ & $3.102 \pm 0.15$ \\
\hline 10 & $0.587 \pm 0.04$ & $0.412 \pm 0.04$ & $0.894 \pm 0.05$ & $1.120 \pm 0.06$ & $3.179 \pm 0.17$ & $2.769 \pm 0.14$ \\
\hline 25 & $0.443 \pm 0.04$ & $0.302 \pm 0.03$ & $0.821 \pm 0.04$ & $0.882 \pm 0.05$ & $2.866 \pm 0.12$ & $2.543 \pm 0.12$ \\
\hline 50 & $0.322 \pm 0.03$ & $0.278 \pm 0.03$ & $0.568 \pm 0.03$ & $0.659 \pm 0.05$ & $2.130 \pm 0.11$ & $1.732 \pm 0.08$ \\
\hline 75 & $0.212 \pm 0.03$ & $0.173 \pm 0.03$ & $0.412 \pm 0.03$ & $0.564 \pm 0.04$ & $1.985 \pm 0.09$ & $1.452 \pm 0.06$ \\
\hline 100 & $0.200 \pm 0.02$ & $0.128 \pm 0.02$ & $0.387 \pm 0.02$ & $0.321 \pm 0.04$ & $1.767 \pm 0.07$ & $1.222 \pm 0.03$ \\
\hline 200 & $0.187 \pm 0.01$ & $0.114 \pm 0.01$ & $0.285 \pm 0.01$ & $0.200 \pm 0.03$ & $1.650 \pm 0.06$ & $1.110 \pm 0.03$ \\
\hline
\end{tabular}

\pm Standard deviation.

Since nitrogen content of plants reduced by metal stress ultimately the biochemical contents of plants also got reduced (Crooke and Inkson, 1955; Mayz and Cartwright, 1984). The mineral elements such as nitrogen, phosphorus, potassium, calcium, magnesium, manganese, iron, copper and zinc content of paddy are gradually decreased with the increase in chromium concentrations (Table 3 ).

It may be due to competition of chromium ions with potassium, which in turn exercised a regulatory control on potassium uptake (Lanoreaux and Chaney, 1978). While the chromium accumulation increased gradually with the increase in chromium concentrations. 
Among treatments, a higher chromium content of paddy was observed in $200 \mathrm{mg} / \mathrm{l}$ chromium concentrations when compared to other chromium treatments. Similarly root accumulate higher amount of chromium than in shoot. It could be due to immobilization of chromium in the vacuoles of the root cells, thus rendering it less toxic, which may be a natural toxicity response of the plant (Shanker et al., 2004a).

Table 3. Nutrient composition and chromium accumulation of paddy (Oryza sativa L.) under different concentrations of chromium.

\begin{tabular}{|c|c|c|c|c|c|c|c|c|c|c|}
\hline $\begin{array}{c}\text { Chromium } \\
\text { concentrations } \\
(\mathrm{mg} / \mathrm{l})\end{array}$ & $\begin{array}{c}\mathrm{N} \\
(\mu \mathrm{g} / \mathrm{g})\end{array}$ & $\begin{array}{c}\text { P } \\
(\mu \mathrm{g} / \mathrm{g})\end{array}$ & $\begin{array}{c}\mathrm{K} \\
(\mu \mathrm{g} / \mathrm{g})\end{array}$ & $\begin{array}{c}\mathrm{Ca} \\
(\mathrm{ppm})\end{array}$ & $\begin{array}{c}\mathrm{Mg} \\
(\mathrm{ppm})\end{array}$ & $\begin{array}{c}\mathrm{Fe} \\
(\mathrm{ppm})\end{array}$ & $\begin{array}{c}\mathrm{Zn} \\
(\mathrm{ppm})\end{array}$ & $\begin{array}{c}\mathrm{Cu} \\
(\mathrm{ppm})\end{array}$ & $\begin{array}{c}\mathrm{Mn} \\
(\mathrm{ppm})\end{array}$ & $\begin{array}{l}\text { Chromium } \\
\qquad(\mu \mathrm{g} / \mathrm{g})\end{array}$ \\
\hline Control & $\begin{array}{r}72.0 \\
\pm 3.6\end{array}$ & $\begin{array}{c}18.2 \\
\pm 0.91\end{array}$ & $\begin{array}{l}50.0 \\
\pm 2.0\end{array}$ & $\begin{array}{r}30.0 \\
\pm 1.2\end{array}$ & $\begin{array}{r}20.0 \\
\pm 1.0\end{array}$ & $\begin{array}{c}32.5 \\
\pm 1.62\end{array}$ & $\begin{array}{c}36.2 \\
\pm 1.44\end{array}$ & $\begin{array}{c}16.0 \\
\pm 0.85\end{array}$ & $\begin{array}{r}45.0 \\
\pm 1.8\end{array}$ & --- \\
\hline 2.5 & $\begin{array}{r}70.5 \\
\pm 3.2\end{array}$ & $\begin{array}{c}16.0 \\
\pm 0.88\end{array}$ & $\begin{array}{r}48.0 \\
\pm 2.4\end{array}$ & $\begin{array}{r}29.0 \\
\pm 1.2\end{array}$ & $\begin{array}{r}18.5 \\
\pm 1.0\end{array}$ & $\begin{array}{c}30.5 \\
\pm 1.60\end{array}$ & $\begin{array}{c}34.5 \\
\pm 1.40\end{array}$ & $\begin{array}{c}15.0 \\
\pm 0.80\end{array}$ & $\begin{array}{r}43.5 \\
\pm 1.8\end{array}$ & $\begin{array}{r}10.5 \\
\pm 0.9\end{array}$ \\
\hline 5 & $\begin{array}{r}66.3 \\
\pm 3.3\end{array}$ & $\begin{array}{r}15.5 \\
\pm 0.85\end{array}$ & $\begin{array}{r}47.5 \\
\pm 2.37\end{array}$ & $\begin{array}{r}27.5 \\
\pm 1.3\end{array}$ & $\begin{array}{r}18.0 \\
\pm 0.9\end{array}$ & $\begin{array}{c}28.6 \\
\pm 1.55\end{array}$ & $\begin{array}{r}30.5 \\
\pm 1.5\end{array}$ & $\begin{array}{c}14.5 \\
\pm 0.72\end{array}$ & $\begin{array}{c}40.2 \\
\pm 1.6\end{array}$ & $\begin{array}{r}12.0 \\
\pm 1.0\end{array}$ \\
\hline 10 & $\begin{array}{c}60.1 \\
\pm 3.0\end{array}$ & $\begin{array}{c}14.3 \\
\pm 0.80\end{array}$ & $\begin{array}{r}47.0 \\
\pm 2.2\end{array}$ & $\begin{array}{r}25.5 \\
\pm 1.2\end{array}$ & $\begin{array}{r}16.5 \\
\pm 0.82\end{array}$ & $\begin{array}{c}27.2 \\
\pm 1.40\end{array}$ & $\begin{array}{r}29.2 \\
\pm 1.5\end{array}$ & $\begin{array}{c}13.5 \\
\pm 0.65\end{array}$ & $\begin{array}{c}38.5 \\
\pm 1.6\end{array}$ & $\begin{array}{r}16.5 \\
\pm 1.0\end{array}$ \\
\hline 25 & $\begin{array}{r}48.5 \\
\pm 2.8\end{array}$ & $\begin{array}{c}12.2 \\
\pm 0.70\end{array}$ & $\begin{array}{r}43.5 \\
\pm 2.0\end{array}$ & $\begin{array}{r}25.0 \\
\pm 1.2\end{array}$ & $\begin{array}{c}16.2 \\
\pm 0.80\end{array}$ & $\begin{array}{c}26.2 \\
\pm 1.31\end{array}$ & $\begin{array}{r}27.5 \\
\pm 1.4\end{array}$ & $\begin{array}{c}13.0 \\
\pm 0.60\end{array}$ & $\begin{array}{c}35.0 \\
\pm 1.7\end{array}$ & $\begin{array}{r}22.2 \\
\pm 1.0\end{array}$ \\
\hline 50 & $\begin{array}{r}43.2 \\
\pm 2.5\end{array}$ & $\begin{array}{r}11.5 \\
\pm 0.65\end{array}$ & $\begin{array}{r}35.2 \\
\pm 1.8\end{array}$ & $\begin{array}{r}23.5 \\
\pm 1.1\end{array}$ & $\begin{array}{c}15.0 \\
\pm 0.75\end{array}$ & $\begin{array}{c}24.5 \\
\pm 1.30\end{array}$ & $\begin{array}{r}27.0 \\
\pm 1.4\end{array}$ & $\begin{array}{c}12.5 \\
\pm 0.55\end{array}$ & $\begin{array}{r}33.5 \\
\pm 1.5\end{array}$ & $\begin{array}{r}24.0 \\
\pm 1.0\end{array}$ \\
\hline 75 & $\begin{array}{r}36.5 \\
\pm 2.5\end{array}$ & $\begin{array}{c}10.2 \\
\pm 0.63\end{array}$ & $\begin{array}{c}30.2 \\
\pm 1.6\end{array}$ & $\begin{array}{r}22.0 \\
\pm 1.1\end{array}$ & $\begin{array}{c}14.0 \\
\pm 0.70\end{array}$ & $\begin{array}{c}22.0 \\
\pm 1.25\end{array}$ & $\begin{array}{r}25.5 \\
\pm 1.3\end{array}$ & $\begin{array}{c}12.2 \\
\pm 0.50\end{array}$ & $\begin{array}{l}30.2 \\
\pm 1.6\end{array}$ & $\begin{array}{r}25.5 \\
\pm 1.2\end{array}$ \\
\hline 100 & $\begin{array}{r}28.2 \\
\pm 2.3\end{array}$ & $\begin{array}{c}9.5 \\
\pm 0.66\end{array}$ & $\begin{array}{l}28.6 \\
\pm 1.5\end{array}$ & $\begin{array}{l}20.2 \\
\pm 1.0\end{array}$ & $\begin{array}{c}12.2 \\
\pm 0.60\end{array}$ & $\begin{array}{c}20.5 \\
\pm 1.20\end{array}$ & $\begin{array}{r}23.0 \\
\pm 1.2\end{array}$ & $\begin{array}{l}10.00 \\
\pm 0.50\end{array}$ & $\begin{array}{r}28.6 \\
\pm 1.2\end{array}$ & $\begin{array}{r}28.2 \\
\pm 1.0\end{array}$ \\
\hline 200 & $\begin{array}{l}26.2 \\
\pm 2.0\end{array}$ & $\begin{array}{c}8.2 \\
\pm 0.51\end{array}$ & $\begin{array}{r}24.5 \\
\pm 1.5\end{array}$ & $\begin{array}{c}19.5 \\
\pm 0.60\end{array}$ & $\begin{array}{c}10.1 \\
\pm 0.60\end{array}$ & $\begin{array}{c}20.0 \\
\pm 1.10\end{array}$ & $\begin{array}{l}22.0 \\
\pm 1.2\end{array}$ & $\begin{array}{c}9.2 \\
\pm 0.40\end{array}$ & $\begin{array}{l}27.00 \\
\pm 1.2\end{array}$ & $\begin{array}{r}30.0 \\
\pm 1.0\end{array}$ \\
\hline
\end{tabular}

\pm Standard deviation.

\section{CONCLUSION}

It can be concluded that the level of chromium above $200 \mathrm{mg} / \mathrm{l}$ is proved to be lethal to paddy crop. However, chromium contaminated water can be properly treated and then discharged into nearby water bodies in order to prevent water pollution. Both government and public sector should join hands in the creation of a clean and green environment. 


\section{References}

[1] Abbassi S.S., Abbassi N., Soni R. (1998). Heavy metals in the environment, Mittal Publication, New Delhi, India.

[2] Ali NA, Ater M.; Sunahara, Gl. and Robidoux, P.Y. (2004). Phytotoxicity and bioacuumulation of copper and chromium using barley (Hordeum Vulgare L.) in spiked artificial and natural forest soils. Ecotoxicology and environmental safety 57: 363-374.

[3] Arnon, D.I. (1949). Copper enzymes in isolated chloroplasts polyphenol oxidase in Beta vulgaris. Plant Physiol., 24: 1-15

[4] Assche F. Van, H. Clijsters, Plant Cell Environ. 13 (1990) 195-206.

[5] Bitell, J.E., D.E. Koeppe and R.J. Miller, 1974. Sorption of heavy metal cations by corn mitochondria and the effects on electron and energy transfer reactions. Physiol.

Plantarum, 30: 226-230.

[6] Black, C.A., 1965. In: Methods of Soil Analysis Part 2. Chemical and Microbiological Properties, American Society of Agronomy, Inc., Madison, Wisconsin, p. 242.

[7] Cervantes, C.; Campos-Garcia, J.; Debars, S.; Gutierrez-Corona, F.; Loza-Tavera, H.; Carlos-Tarres-Guzman, M. and Moreno-Sanchez, R. (2001). Interaction of chromium with Microgenesis and plants. FEMS Microbiol. Rev., 25: 335-347.

[8] Chatterjee J., Chatterjee, C., Environ. Pollut. 109 (2000) 69-74.

[9] Crooke W.M., R.H.E. Inkson, Plant Soil 6 (1995) 1-15.

[10] Dua A., S.K. Sawhney, Environ. Exp. Bot. 31 (1991) 133-139.

[11] Dube, B.K.; Tewari, K.; Chatterjee, J. and Chaterejee, C. (2003). Excess chromium alters uptake and translocation of certain nutrients in citrullus. Chemosphere 53: 1147-1153.

[12] Dubois, M., K.A. Gilles, J.K. Hamilton, P.A. Rebers and F. Smith, 1956. Colorimetric method for determination of sugars and related substances. Anal. Chem., 28: 350-356.

[13] Jackson, M.L., 1958. Soil chemical analysis. Prentice Hall of India Private Limited, New Delhi, pp. 22-23.

[14] Kirk, J.T.O. and R.L. Allen, 1965. Dependence of chloroplast pigments synthesis on protein synthetic effects of acitilione. Biochem. Biophys. Res. Commun., 27: 523-530.

[15] Krishnamurthy S., Wilkens M.M., Northeasteren geology 16 (1994) 14-17.

[16] Lakshmi S., P. Sundaramoorthy, J. Ecobiol. 15 (2003) 7-11.

[17] Lalitha, K., N. Balasubramanian and S. Kalavathy, 1999. Studies of impact of chromium on Vigna unguiculata (L.) Walp. var. Long. J. Swamy Bot. Cl., 16: 17-20.

[18] Lanoreaux R.J.W.R., S. Chaney, Plant Physiol. 43 (1978) 231-236.

[19] Lowry, O.H., N.J. Rosenbrough, A.L. Farr and R.J. Randall, 1951. Protein measurement with folin-phenol reagent. J. Biol. Chem., 193: 265-275.

[20] Mayz D.M.J., P.M. Cartwright, Plant Soil 80 (1984) 423-430. 
[21] Moore, S. and W.H. Stein, 1948. Photometric method for use in the chromatography of amino acids. J. Biol. Chem., 176-388.

[22] Nelson, N., 1944. A photometric adaptation of the Somogyis method for the determination of reducing sugar. Anal. Chem., 3: 426-428.

[23] Pillay A. E., et al., Environ. Intl. 1048 (2003) 1-5.

[24] Piper, C., 1966. Soil and plant analysis. Asian Hans Publishers, Bombay, pp. 11-36.

[25] Rai U. N., Tripathi R. D., Kumar N., Chromosphere 25 (1992) 721-732.

[26] Rout, G.R., S. Samantary and P. Das, J. Plant Nutr. 20 (1997) 473-483.

[27] Samantary, S. and B. Deo, 2004. Studies on chromium toxicity in mung bean (Vigna radiata L.). Adv. Plant Sci., 17: 189-194.

[28] Sankar Ganesh K., AL.A. Chidambaram, P. Sundaramoorthy, L. Baskaran M. Selvaraj (a), Indian J. Environ. Ecoplan. 12 (2006) 291-296.

[29] Sankar Ganesh K., L. Baskaran, S. Rajasekaran, K. Sumathi, AL.A. Chidambaram. P. Sundaramoorthy, Colloid. Surface. B 63 (2008) 159-163.

[30] Sankar Ganesh, K., P. Sundaramoorthy and AL.A. Chidambaram, 2006b. Chromium toxicity effect on blackgram, soybean and paddy. Poll. Res., 25: 257-261.

[31] Shanker A.K., C. Cervantes, H.L. Tavera, S. Avudainanyagam, Environ. Int. 31 (2005) 739-753.

[32] Shanker A.K., M. Djanaguiraman, R. Sudhagar, C.N. Chandrashekar, G. Pathmanabhan (a), Plant Sci. 166 (2004) 1035-1043.

[33] Sharma, D. C.; Chatterjee, C. and Sharma, C. P. (1995). Chromium accumulation by barley seedlings (Hordeum vulgare L,). Journal of experimental botany 25: 241-251.

[34] Sharma D.C., Pant R. C., Journal of environmental science and health, Part A 29 (1994) 941-948.

[35] Sidharthan, M. and A.S. Lakshmanachary, 1996. Efficacy of chromium on germination, growth and biochemical studies on Glycine max var. CO 1. In: Jha, P.K., G.P.S. Ghirmire, S.B. Kamacharya, S.R. Baral and P. Lacoul (eds.), Environment and Biodiversity, Ecological Society, Katmandu, Nepal, pp. 326-328.

[36] Subramani, A., P. Sundaramoorthy, S. Saravanan, M. Selvaraj and A.S. Lakshmanachary, 1999. Screening of groundnut cultivars for chromium sensitivity. Ecoprint, 6: 61-65.

[37] Sundaramoorthy, P., K. Sankar Ganesh, L. Baskaran, K. Sumathi, S. Rajasekaran, 2006b. Germination behaviour of some agricultural crops under chromium treatment. Bull. Biol. Sci., 4: 99-101.

[38] Sundaramoorthy, P., K. Sankar Ganesh, S. Rajasekaran, L. Baskaran and K. Sumathi, 2006a. Studies on the effect of chromium on germination and growth of soybean (Glycine max) cultivars. Bull. Agr. Sci., 4: 91-94.

[39] Williams, C.H. and V. Twine, 1960. In: Peach, K. and M.V. Tracey (eds.), Modern Methods of Plant Analysis, Vol. 5, Springer Verlag, Berlin, pp. 3-5. 
[40] Yoshida, S., D. Fordo, J. Cork and K. Gomez, 1972. Laboratory manual for physiological studies of rice, $3^{\text {rd }}$ edn., The International Rice Research Institute, Philippines, pp. 11-23.

[41] Zayed A. M., Terry N., Plant and soil 249 (2003) 139-156.

[42] Zayed A., Lytle C.M., Qian J.H., Terry N., Planta 206 (1998) 293-299. 